\title{
BOOK REVIEW: MEMAHAMI DIALEKTIKA ISLAM NUSANTARA DI INDONESIA
}

\author{
Al Muhammad Nur \\ Pusat Kajian Pakan Madani Padang \\ Email: al_nur@gmail.com
}

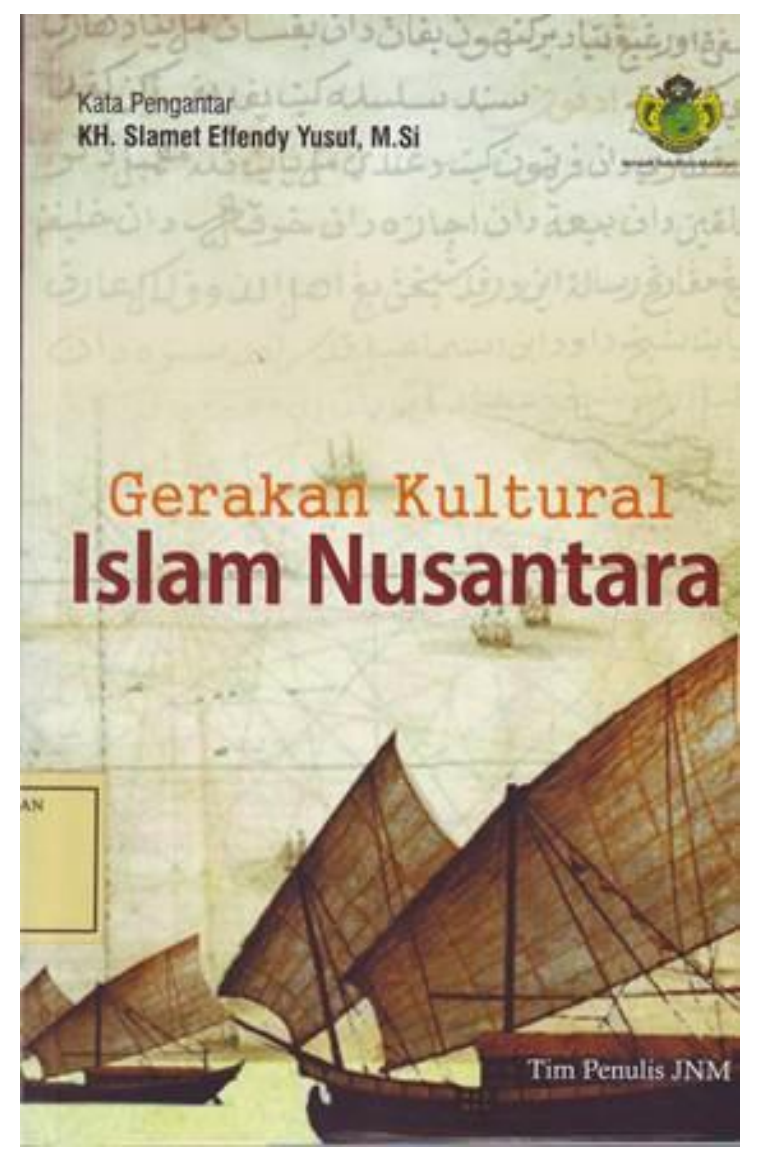

Judul : Gerakan Kultural Islam Nusantara

Penulis : Tim Penulis JNM

Halaman : vii +332 halaman

Penerbit : Jamaah Nahdliyin Mataram, Yogyakarta

Cetakan : Pertama

Tahun : Agustus, 2015

ISLAM NUSANTARA UNTUK Muktamar NU ke-33 Jombang, bertajuk PERADABAN DUNIA MUSLIM Islam Nusantara Untuk Peradaban Dunia

Pengantar buku Gerakan Kultural Islam Nusantara ini ditulis oleh KH. Slamet Effendi Yusuf, M.Si, Ketua SC Panitia Muslim. Yusuf menggambarkan bahwa sejarah umat Islam dalam tradisi politik di Indonesia sangat berpengaruh terhadap 
arah pembangunan peradaban Islam yang rahmatan lil alamin.

Berita kekerasan di Timur Tengah yang berlarut-berlarut masih saja menyelimuti dunia muslim. Kekerasan itu mengambil bentuk perang sektarian, meskipun tujuan dan fakta sebenarnya adalah ekonomi politik. Perang di Suriah dan Irak, yang merembet ke negaranegara tetangga, menggambarkan kengerian. Apa yang terjadi di Timur Tengah, menggambarkan kegagalan kaum muslimin di sana untuk membangun peradaban muslim yang santun, dan mengayomi semua kelompok.

Di belahan bumi yang lain, negaranegara non muslim telah mengalami kemajuan peradaban yang luar biasa, baik di China, Rusia, Amerika, maupun Eropa. Fenomena ini mesti menjadi refleksi serius bagi mereka yang mencintai Islam dan dunia muslim, bahwa kekerasan dan pola kejadian seperti di Suriah, Irak, dan beberapa wilayah tetangganya, justru akan memundurkan peradaban Islam. Membutuhkan bergenerasi-generasi bagi negara-negara muslim itu bisa pulih dan maju. Dengan perang saudara berlarutlarut itu, mereka akan kehilangan generasi baru dan kemunduran generasi. Anakanak yang harusnya membangun negeri mereka, dipaksa memanggul senjata dan menyaksikan saudara-saudara mereka saling bunuh.

Wajah Islam seperti ini, memberikan pandangan kepada muslim di mana-mana tempat, terutama di Indonesia, bahwa kejadian seperti itu mestilah: tidak bisa dan tidak boleh dianggap mewakili tradisi Islam dan karakter Islam di belahan dunia lain; dan kejadian serupa sebisa mungkin dicegah agar tidak terjadi di Indonesia. Hal demikian membutuhkan upaya bahu membahu dari segenap elemen umat Islam, utamanya dari kelompok yang terbesar di dalam masyarakat untuk bisa secara kritis melihat sejarah Timur Tengah, bukan hanya tidak patut ditiru, tetapi justru patut disesali. Penyesalan itu membutuhkan tilikan kritis terhadap upaya-upaya membangun peradaban dunia muslim ke depan, yang berpijak dan mengambil fondasi justru dari Timur Tengah, tanpa harus terjebak pada sikap anti dari dimensi yang baik di sana. Islam yang hadir dan dihadirkan dengan cara kekerasan, yang membabat tradisi rakyat dan keinginan menghancurkan umat manusia, bahkan sesama saudara muslim sendiri adalah preseden, dan tidak sepatutnya didukung untuk menjadi basis di Indonesia.

Kebanyakan dari masyarakat Islam di Nusantara, utamanya yang tinggal di Indonesia, terbiasa akrab dengan ekspresi budaya Islam yang berbeda-beda, di antara pulau-pulau, suku-suku dan bahasa, yang membentuk karakter masyarakat Islam Nusantara. Memang ada saat-saat tertentu terjadi yang tidak diinginkan, tetapi biasanya itu memiliki motif politik atau kepentingan tertentu. Setelah itu, segera saja pembelokan itu dikembalikan ke realnya, yang menempatkan Islam supaya menjadi rahmat dan bermanfaat, untuk memperbaiki hidup dan kehidupan manusia di Indonesia.

\section{SEBUAH RENUNGAN GERAKAN PERUBAHAN}

Buku ini diawali penulisnya dengan ulasan kaum muda NU dan gerakan perubahan dalam dinamikanya. Setiap zaman mempunyai penanda dan nalarnya sendiri. Saat ini bangsa Indonesia sedang mengalami fase ketiga refleksi lima tahunan pasca reformasi. Ada banyak hal yang dulu menjadi cita-cita reformasi, dan saat ini hanya menjadi mimpi, harapan dan masih sekedar cita-cita. Berbagai elemen yang dulu dengan tegas, keras, 
dan kritis mengevaluasi orde baru, baik itu para tokoh, ormas bahkan partai politik, ternyata banyak yang limbung. Ketika mereka ada di pusat kekuasan menjadi terlena dan terbuai oleh nikmat berkuasa dan bergelimang berbagai fasilitas. Kesadaran kemanusiaan dan kebangsaan tidak jarang tergadai dan hilang. Cita-cita bersama reformasi akhirnya menjadi bangkai yang membusuk dimakan oleh keserakahan dan kemunafikan.

Tidak hanya di birokrasi dan pemegang kekuasaan di pemerintahan, pembusukan itu terjadi di semua lini stakeholder perangkat sosial politik berbangsa dan bernegara. Bahkan termasuk ormas dan para aktivis yang dulu dengan gagah dan lantang berteriak soal perubahan. Bisa dikata reformasi telah mengalami stagnasi, dan hari ini bangsa Indonesia dikuasai oleh para pemain dan pemabuk kekuasaan, partai dan ormas mainstrem terbukti gagal mengkader dan melahirkan generasi yang tidak mabuk kuasa.

\section{ISLAM NUSANTARA PERADABAN ISLAM INDONESIA}

(ISNUS): A LA

Isnus dari sudut pengertian, merupakan gabungan dari dua kata, Islam dan Nusantara. Islam merujuk pada agama luhur yang dibawa Kanjeng Nabi Muhammad yang lahir di Mekkah. Dalam perkembangannya agama ini meluas ke segala penjuru dunia. Sedangkan Nusantara adalah wilayah/kawasan yang merujuk pada Indonesia dan sekitarnya di Asia Tenggara, tetapi tidak mencakup secara keseluruhannya, karena tidak semua Asia Tenggara dimasuki Islam atau diairi oleh fondasi Islam.
Mendengar kata Nusantara ini, dalam sejarah dikaitkan dengan konsep yang dibuat oleh kerajaan Majapahit dan Patih Gajah Mada. Akan tetapi konsep Nusantara sebaiknya diperluas dari apa yang didefinisikan oleh Majapahit dan Patih Gajah Mada yang didokumentasikan dalam Kitab Negara Kretagama pada Pupuh 13 dan 14, yang mencakup Semenanjung Melayu (Palembang dan sekitarnya), Gugusan Lawas (Lampung dan sekitarnya), Tanjungnegara (Sampit, Sambas, dan sekitarnya), Tanjung Pura dan sekitarnya, Malaysia sekarang ini, Timur Jawa dari mulai Bali sampai Bima dan deretan hutan di sekitarnya, pulau gurun Lombok Merah, Makassar, Buton, Ambon, Maluku, dan sekitarnya. Hanya saja, perlu digarisbawahi pada zaman itu, wilayah Sunda (GaluhPakuan-Pajajaran), tidak termasuk wilayah kekuasaan Majapahit dan tidak tunduk pada Majapahit.

Nusantara yang dipakai Isnus ini mencakup Indonesia beserta wilayahwilayahnya, dan bangsa-bangsa sekitarnya yang memiliki hubungan dengan tradisi penyebaran Islam di zaman awal, bangsa-bangsa yang dipisahkan oleh lautan (nusa: bangsa, antara: dipisah lautan). Dalam konteks Negara bangsa saat ini, yang dimasukkan dalam konsep Nusantara adalah Indonesia, Malaysia, Brunei, Thailand Selatan, dan beberapa daerah lain dengan pertimbangan tertentu, seperti Timor Leste. Dari penjelasan demikian, masih mungkin ada pengertian dua hal terkait dengan Isnus: merujuk pada pengertian 
kalangan, kelompok, dan masyarakat Islam yang ada di wilayah Nusantara; dan Islam yang memiliki corak tertentu dan berinteraksi secara luwes dengan tradisi atau khazanah Nusantara. Dari dua kemungkinan itu, pengertian pertama dapat digugurkan, karena Nusantara dikaitkan dengan Islam, bermakna ajektif, sifat, dan penyifatan. Sama seperti Islam Arab, Islam Afrika, dan Islam di kawasan lain. Selintas dan secara serampangan tampak maknanya adalah Islam yang ada di kawasan itu. Padahal ketika Islam disambung dengan Nusantara, Arab, Afrika, dan lain-lain, berarti menegaskan ada penyifatan tertentu. Sama juga tentang penyifatan adanya Islam Wahabi, Islam Sunni, Islam Syi'i, dan lain-lain. Dengan kata lain, Isnus adalah Islam yang memiliki karakter dan bercorak Nusantara yang mengakomodasi tradisi-tradisi dan alam pikiran orang Nusantara, dengan tetap dan berangkat dari titik pijak Islam. Karenanya, ada satu titik pijak dari Islam yang memiliki kesamaan di mana-mana, dan dapat dicari kesamaannya dengan Islam di manapun. Akan tetapi, juga ada halhal yang mungkin hanya dapat ditemukan di wilayah Nusantara, sehingga menjadi bagian dari khazanah yang dikembangkan oleh Isnus. Bentuk, perwujudan, dan ekspresi Isnus bisa bermacam-macam karena di dalamnya tidak mengandaikan satu ketunggalan, tetapi memiliki karakter dan corak yang dapat mempersamakan. Dalam dunia kontemporer atau saat ini, perwujudan Isnus bisa diwakili oleh ratusan organisasi- organisasi tarekat, menjamurnya ormas yang bermadzhab, tetapi juga menenggang adat, dan mewakili sebuah semangat hidup, tradisi, dan khazanah dalam gugusan Isnus yang tersebar di seantero Nusantara.

Dengan demikian, Isnus adalah masalah memperjuangkan keyakinan, pandangan hidup, jalan keselamatan, dan dunia lahir-batin bagi masyarakat Nusantara, dan Indonesia khususnya. Yang dicari dan ingin dikemukakan dengan Isnus bukan soal unik atau tidak, dan bukan soal di tempat-tempat lain ada apa tidak. Karenanya Isnus hanya memperkenalkan kembali, memformulasi, dan memunculkan apa yang sudah ada; apa yang telah dipraktikkan, apa yang dijadikan rujukan; dan khazanah-khazanah yang ada dalam masyarakat Isnus.

Satu hal penting sebelum membicarakan hal-hal lain yang berkaitan dengan Isnus, soal gerakan kultural di dalam tradisi kalangan muslim, penting dibahas. Sebab, tradisi gerakan kultural di kalangan Islam dan dunia muslim ini membentuk kekuatan Islam Tradisi, yang dalam kasus di Nusantara, proses ini membentuk Isnus. Gerakan kultural ini mengambil tipe dan corak dalam gerakan Islam yang bertumpu pada kekuatan rakyat sipil, berbekal konstruksi pengetahuan, dan mengandalkan kekuatan moral. Tradisi gerakan kultural yang kemudian membentuk pola Islam 
Tradisi di dalam dunia muslim, muncul bersamaan dengan sejarah Islam itu sendiri. Gerakan kultural ini dilakukan dan dipimpin oleh tokohtokoh muslim generasi awal dari kalangan tasawuf atau sufi, kemudian dilakukan para faqih, dan diikuti bidang-bidang yang lainnya, termasuk di bidang teologi. Gerakan kultural ini mengambil peran membangun masyarakat Islam, di luar prakarsa dan dikte kekuasaan politik yang dikendalikan militer, meskipun tetap ada di dalam lingkup dan wilayah kekuasaan politik itu sendiri.

Inti dari gerakan kultural ini, awalnya muncul dari gerakan tasawuf, yang berakar dari Islam sendiri sejak zaman Nabi. Gerakan ini berupaya membentuk kehidupan luhur bagi pribadi-pribadi muslim. Wujud gerakan ini adalah laku zuhud dan asketis yang dilakuka para sahabat. Pada zaman Nabi, Masjid Nabawi, salah satu serambinya menjadi pusat dari gerakan ini, yang dalam kitabkitab babon tasawuf, misalnya dalam kitab yang ditulis al-Kalabadzi yang berjudul at-Ta`aruf li Madzhabi Ahli atTashawwuf, dan Hilyatul Auliya wa Thabaqatul Ashfiya' yang dikarang oleh Abu Nu'aim al-Ashfihani, mereka disebut sebagai ahlu shuffah. Gerakan ini semakin massif di kalangan orangorang shaleh kritis, bersamaan dengan munculnya pergolakan politik di kalangan umat Islam saat itu yang semakin menampilkan kekacauan.

Isnus adalah bagian dari Islam Tradisi yang hidup di Nusantara, melalui jalan yang mula-mula adalah gerakan kultural. Beberapa tilikan dalam refleksi dan Jasmerah di bagian sebelum ini, telah jelas, bahwa gerakan kultural dilakukan para penyebar Islam. Dan jelas pula, hingga hari ini hal itu diteruskan, meskipun tetap mengakomodasi jalan politikkekuasaan di dalam sejarah perjalanannya.Peradaban, perkembangan, dan hidup Isnus diairi oleh akar dari Islam Tradisi itu, yaitu jalan tasawuf dan gerakan kultural ini.

Hal ini terlihat pada fase sebelum abad ke-16, Islam datang ke Nusantara diinisiasi oleh para pendakwah dari kalangan sufi, bersama-sama bergandengan dengan para pedagang di daerah-daerah pesisir. Di Jawa mereka dikenal dengan istilah Wali Songo dari mulai generasi pertama hingga generasi terakhir (awal berdirinya Kerajaan Mataram Islam). Nama- nama pendakwah generasi pertama, di antaranya adalah Syaikh Subakir yang memiliki keahlian menumbal tanah Jawa agar tawar dan bisa menerima Islam. Petilasannya ada di Gunung Tidar, Magelang.

Jauh sebelum itu, Mbah Bangil atau Syaikh Ismail pada tahun $680 \mathrm{M}$ sudah menyebarkan Islam di Jawa Timur. Tahun itu tatkala kekuasaan dunia Islam ada di tangan kekhilafahan Dinasti Umayyah. Selain itu juga ada Maulana Ali Syamsu Zain yang hidup pada zaman Prabu Jaya Baya dan menjadi guru di Kediri. Generasi mereka diteruskan para Wali Songo berikutnya, yang makammakamnya masih bisa dilacak dan diziarahi oleh para peziarah di 
kalangan Islam Tradisi di Nusantara.

Di luar pulau Jawa, Islamisasi awal juga dilakukan dengan jalan kultural lewat jalur perdagangan dan sufi. Yang terawal adalah di Sumatera, yang pada abad ke-7 masa Dinasti Umayyah sudah ada orang-orang Islam di Sriwijaya/Jambi yang saat itu bernama Muara Sabak, masuk Islam. Ada korespondensi antara Khalifah Umayyah,Umar bin Abdul Aziz dengan Sri Maharaja Lomasyarakatwarman soal Islam. Pengganti Sri Maharaja Lomasyarakatwarman, yaitu Sri Maharaja Srindawarman akhirnya diberitakan memeluk Islam. Korespondensi mereka ini dokumennya masih tersimpan di Museum Spanyol di Madrid. Hanya saja, wilayah ini kemudian berubah menjadi kekuasaan dalam pengaruh Kekaisaran China yang menganut agama Budha Mahayana, yang mampu menyingkirkan orang- orang Islam dalam pengaruh perdagangan lada di Sriwijaya. Di tempat-tempat lain, seperti di Aceh dan Melayu, menurut Abu Bakar Atjeh dalam buku Sekitar Masuknya Islam ke Indonesia, Islam datang mula-mula dilakukan oleh pendakwah, yang bernama Syaikh Ismail (namanya sama dengan yang di Bangil). Orang ini berhasil mengislamkan Raja Pasai, tetapi sebelum itu juga sudah banyak ditemukan makam-makam dari orang Islam di Aceh. Masih di tempat lain, dalam Buku Sejarah Perkembangan Islam di Timur Jauh yang ditulis Mufti Johor, bernama Sayyid Alwi bin Thahir al-Haddad, menyebut nama Syarif
Muhammad bin Ali Zainul Abidin, yang mula-mula mengembangkan Islam di Mindanau Utara di tempat yang terkenal dengan nama Pulangi. Kemudian ia menjadi Wali di Mindanau. Ceritanya yang panjang itu ditulis dalam bukunya bernama Sejarah Mangindanau. Sayyid Thahir al-Haddad juga menerangkan bahwa pembawa Islam itu ada hubungan keturunan dengan Ali Zainal Abidin (cucu Nabi Muhammad) yang berangkat dari Hadramaut (Arab Selatan) ke Johor di Semenanjung Melayu.

Pada fase sesudah abad ke-16, ditandai dengan munculnya jaringan intelekual para murid Haramain, di antaranya yang tertua dan bisa dilacak adalah Syaikh Abdurrauf as-Sinkili, yang mengajarkan tarekat Syathariyah dan lahir pada tahun $1615 \mathrm{M}$. Tokoh ini memiliki banyak murid, termasuk penyebar-penyebar Islam awal di Jawa, seperti Syaikh Abdul Muhyi. Dari tokoh ini dan generasi seangkatannya atau sesudahnya di seantero Nusantara, corak Islam sufistik semakin memperoleh bentuk bergandengan dengan syariat yang diajarkan di Haramain.

Sampai munculnya kolonialisme Portugis, Inggris, Belanda, dan Jepang, dan hilangnya kerajaan-kerajaan Islam secara formal-substansial, gerakan kultural Isnus semakin kuat, karena mengambil bentuk dalam pilarpilar di pesantren, dayah, dan masjid. Pada angkatan ini, Syaikhona Kholil, Hadhratus Syaikh Hasyim Asyari, dan angkatan mereka di Nusantara, yang 
telah kembali dari Haramain, memperkuat konsolidasi gerakan kultural Isnus bercorak sufistik yang direkonsiliasi dengan syariat, dan terbentuknya organisasi-organisasi modern di kalangan masyarakat Isnus, di seantero Nusantara.

Jadi, hapusnya kerajaankerajaan Islam pada zaman kolonial, dan munculnya negara-bangsa, pada sisi lain memperkuat gerakan kultural di kalangan Islam Tradisi yang mengembangkan Isnus, karena mereka harus berpijak pada akar dan bergerak di penyangga-penyangga Isnus di lima pilar, ketika kerajaan sudah tidak ada, yaitu masjid, dayahpesantren, tradisi, makam, dan tarekat. Gempuran tantangan modernitas, arus baru Wahabisme dan Islam-Islam anyaran yang juga bergerak secara kultural karena tidak memperoleh tempat di politik, dan KatholikKristen yang melakukan inkulturasi dalam gerakan kultural, ganti menjadi tantangan yang mesti dan harus berjibaku dengan Isnus.

\section{AKTOR, TRANSFORMASIONAL DAN NILAI-NIILAI ISLAM NUSANTARA}

Kehadiran Islam di Nusantara memiliki karakteristik khas yang membedakan dengan kawasan lainnya. Ia tidak disebarkan dengan ekspansi (al-fath) sebagaimana yang terjadi di kebanyakan negara Islam seperti Timur Tengah, Rum-Turki dan Mesir, akan tetapi dengan sebuah kearifan sejarah melalui ulamaulamanya yang datang dari Timur
Tengah, India (Malibar, Karamandel dan Gujarat) dan Rum dengan pendekatan secara kultural (seperti mengakulturasi budaya lokal selagi tidak bertentangan dengan ajaran Islam), mendirikan paguronan (padepokan atau pesantren), pernikahan, perdagangan dan tasawuf. Dengan cara seperti ini, para dai dan muballigh berhasil mentransformasikan Nusantara yang awalnya merupakan daerah yang berbasis Kapitayan dan Hindu-Budha menjadi kawasan yang mayoritas penduduknya memeluk agama Islam terbesar sedunia. Buah keberhasilan metodologi kebudayaan tersebut berimplikasi pada hadirnya wajah sosiologis dan antropologis Islam yang begitu ramah dan transformatife di Nusantara. Saat Islam datang di Nusantara sejak abad ke-7 hingga pada zaman kerajaan Sriwijaya dan Majapahit, dengan toleransinya, ia dapat berkembang dinamis dan koeksisten bersama penduduk lokal, sehingga terciptalah perkampungan Islam seperti Zabak dan Sribusa di Palembang-Sriwijaya dan padepokan Bejagung (Tuban) pada zaman Majapahit pada zaman Prabu Hayam Wuruk dan Patih Gajah Mada. Perlahan namun pasti, eksistensi gigi religi pengaruh kerajaan-kerajaan besar mulai mengalami kemandegan ketika Islam datang. Tak sedikit dari mereka yang mengatakan Islam merupakan virus yang akan mematikan tatanan keagamaan dan sosial yang selama ini telah mentradisi berurat akar. Namun kenyataannya, Islam mampu 
berkomunikasi secara aktif dan meyakinkan elite-elite kerajaan untuk mulai membuka mata dan fikiran atas segenap bentangan besar kisah-kisah dunia. Islam merupakan anak zaman dari beragam pergulatan puak-puak bangsa yang berhasil menunjukkan diri sebagai pemangku nilai-nilai pencerahan dengan semangat menjaga tradisi dan menerima pelbagai pengaruh kabaharuan, semata-mata untuk mengemas perkakas-perkasas dakwah mutakhir yang digunakan dalam proses dakwahnya.

Ketika Islam berkembang di Nusantara, para muballigh selalu memprioritaskan untuk mendirikan masjid dan pesantren sebagai wadah untuk mendidik kader-kader ulama yang nantinya akan meneruskan perjuangannya dalam menyebarkan agama Islam di Nusantara. Sebagai contoh kecilnya, di Aceh ada Masjid Baiturrahman yang didirikan Sultan Mahmud I pada 1292. Masjid ini tidak hanya sebagai tempat ibadah, melainkan sebagai universitas Islam Nusantara yang di dalamnya digelar berbagai telaah disiplin ilmu keislaman. Untuk menambah bobot kajiannya, diundanglah alim ulama dari manca untuk menyuguhkan ilmu di masjid tersebut, seperti India, Arab, Turky dan Persia. Selain Masjid Baiturrahman yang menjadi pusat peradaban Islam Nusantara di Aceh, pesantren yang didirikan oleh Syaikh Abdurrauf alSinkeli tidak kalah pentingnya dalam mendukung laju perkembangan Islam di Aceh hingga membentang ke Nusantara melalui murid-muridnya yang berasal dari berbagai kawasan Nusantara seperti Syaikh Burhanudin Ulakan yang menyebarkan agama Islam di daerah Minangkabau dan Syaikh Muhyi Waliyullah Pamijahan yang menyebarkan Islam di pulau Jawa, khususnya di Tasikmalaya.

Untuk wilayah Jawa, contoh masjid dan pesantren yang menjadi pusat perkembangan agama Islam adalah seperti Masjid Ampel Denta beserta pesantren yang didirikan Sunan Ampel, Masjid Bintoro (Demak), Pesantren Giri dan beberapa pesantren atau masjid yang didirikan Walisongo dan murid-muridnya. Antusias dalam memakmurkan masjid sebagai tempat ibadah dan tafaqquh fiddin tidak hanya datang dari kalangan ulamanya, akan tetapi pemerintahannya juga sangat memperhatikan hal tersebut semisal Sultan Malikuz Zahir (Sultan Samudra Pasai kedua).

Kita meyakini adagium atau doktrin al-Islam sholih fi kulli al-zaman wal-makan. Islam kita pandang dipandang sebagai agama yang senantiasa sesuai, cocok, relevan secara sosial dan intelektual, di setiap konteks waktu dan ruang. Islam senantiasa meruang dan mewaktu. Tidak pernah ahistoris dan ketinggalan zaman. Segala sesuatunya telah diatur dalam Islam, tidak ada yang tidak diatur dalam Islam, ada yang terperinci namun ada juga yang secara garis besar atau prinsip dasar umum. Dalam bahasa falsafah, kita sepenuhnya meyakini Islam membawa kebenaran perenial. 
Hadits Kanjeng Nabi Muhammad Saw. dalam haji wada' atau isyarat Al Qur'an bahwa tidak ada satupun yang dilupakan oleh Allah swt. dalam kitab suci, merupakan rujukan yang menjadi dasar keyakinan teologis di atas. Akan tetapi, untuk mewujudkannya dalam realitas empirik tidak seperti jika kita menunggu hujan yang datang dari langit. Hal tersebut Isnus membutuhkan sentuhan-sentuhan ijtihadiyyah yang keras dan terus menerus. Di sinilah Isnus secara niscaya dihadapkan problemproblem kekinian yang harus dijawab sebagaimana Isnus telah secara meyakinkan menjawab tantangan masa lalu. Untuk menjawab persoalan ini kita harus menyelami atau memahami struktur yang disebut dengan "kebutuhan obyektif". Pemahaman akan persoalan sekaligus jawaban paradigmatik terhadap "kebutuhan obyektif" inilah yang akan menghasilkan suatu formula Isnus yang indegenous. Di sini penulis hanya akan memberikan beberapa sketsa besar yang menjadi tantangan bagi pengembangan pemikiran keislaman Nusantara. Pijakannya utamanya tentu saja adalah Isnus sebagai rohmatan lil-'alamiin.

Konstruksi Isnus tersebut membutuhkan kapasitas kekuatan sumber daya dan "kaki" terutama dalam kaitannya sebagai organisasi sosial keagamaan. Kekuatan sumber daya ini baru akan massif jika terhimpun dari sinergisitas antarkekuatan. Paling tidak Isnus sebagai gerakan pemikiran dan sosial harus memiliki tiga lapis kekuatan kader. Pertama, kekuatan basis. Kekuatan yang cukup menentukan dinamika gerak pemikiran dan sosial Isnus. Mereka adalah semua kader basis Isnus yang telah terdidik secara organisasi. Kekuatan basis ini baru akan memiliki daya dorong dalam konteks kelembagaan ketika berhasil menyelesaikan kontradiksikontradiksi internalnya, secara ideologis cukup kuat, dibekali perangkat metodologi analisis, dan memiliki kapasitas manajerial memadahi. Kedua, kekuatan pelopor. Mereka adalah minoritas kreatif yang menjadi vanguardist, dalam gerakan, militan, ideologis, dan memiliki kekuatan spiritual memadahi. Mereka adalah lapisan kader yang menjadi motor penggerak berbagai formasi gerakan Isnus. Ketiga, kekuatan inti. Semacam think thank yang memiliki kualifikasi seperti kader pelopor namun memiliki kekuatan urai sosial, tajam dan maqom spiritual yang tinggi. Dalam bahasa gerakan sosial, struktur organisasi Isnus haruslah mampu merefleksikan tiga lapis kekuatannya, yakni level kepemimpinan yang memiliki maqom spiritualitas tinggi, berintegritas, memahami alur sejarah, politik, dan ekonomi sehingga mampu memberikan penjelasan historis serta arahan-arahan, dan perspektif yang visioner. Level tengah yang berfungsi memerankan kerjakerja manajerial sekaligus mengakomunikasikan kegelisahan basis dan gerak sejarah serta menerjemahkan 
bangunan visi dalam bahasa yang dipahami basis.

Gerakan pemikiran dan sosial Isnus tersebut akan mencapai transfomasi, yakni kristalisasi dan sublimasi keseluruhan gerakan setelah melalui tahapan berikut ini: pertama, pemahaman pegiat Isnus terhadap kondisi objektif yang senantiasa mengalami pergeseran. Kedua, mampu melakukan kontekstualisasi Isnus dalam level praksis empiris. Mampu merumuskan berbagai isu-isu strategis, tahapan-tahapan, taktik, yang tidak utopis. Ketiga, Isnus mampu mengidentifikasi akar persoalan dan aktor pada dataran struktural dan kultural sehingga mampu melakukan blocking area dan memahami medan perjuangan. Keempat, mampu menjadi konsolidator gerakan baik konteks Nahdhiyin maupun elemen-elemen lain. Kelima, mampu menyusun strategic planning, scenario building, dan action planning. Keenam, mampu membangun kesadaran kritis masyarakat sehingga mampu mentransformasikan Isnus menjadi isu masyarakat sehingga masyarakat menjadi aktor utama perubahan.

\section{MELACAK JEJAK DAN IDENTITAS DALAM PERADABAN}

Bagian ini ingin menjelaskan sumbu utama untuk melihat secara lebih dalam dinamika perkembangan Isnus. Fokusnya melihat kembali jejak historis, arkeologis dan sosiologis khazanah perdagangan melalui pelayaran sejak abad 7 dan abad 8 yang mempertemukan hubungan dagang laut antara Kekhalifahan Umayah (660-749 M) di Asia Barat, dinasti T’ang (618-907 M) di Asia Timur, dan Kerajaan Sriwijaya (7-14 M) di Asia Tenggara. Jalur perdagangan laut yang mulai ramai sejak abad itu memberi jalan bagi berkembangnya pusat perekonomian dan kebudayaan lainnya, utamanya adalah proses menyebarnya Islam sebagai agama yang mulai diterima sebagai keyakinan oleh masyarakat Nusantara.

Intensitas persentuhan para pedagang muslim dengan penduduk setempat memungkinkan persemaian keberagamaan itu terjalin, tak heran bila pada abad $13 \mathrm{M}$, sudah muncul kerajaan Islam pertama Samudera Pasai yang secara geografis berdekatan dengan Malaka. Malaka sebagai pusat pelabuhan, kala itu menjadi persinggahan para saudagar India, Persia, Tiongkok, Arab dan Eropa yang akan masuk ke Nusantara. Dari pelabuhan Malaka inilah, proses perniagaan melalui pelayaran yang beriringan dengan Islamisasi masuk ke pantai utara Pulau Jawa seperti Sunda Kelapa, Banten, Jepara, Tuban, Gresik, Surabaya dan Madura serta beberapa pulau lainnya di Indonesia.

Sejarah dan perkembangan Islam di Indonesia memerlukan proses yang sangat panjang dan berliku melalui saluran-saluran sosialisasi - atau orang lazim menyebutnya "Islamisasi" yang beragam, seperti perdagangan, perkawinan, tarekat (tasawuf), pendidikan dan termasuk ke(seni)an. Pada tahap awal Islamisasi, 
Bentuk nyata dari kesuksesan ini bisa dilihat pada keberadaan masjid Menara Kudus. Masjid ini didirikan oleh Sunan Kudus pada 1549 M/956 $\mathrm{H}$ dengan nama Masjid Al Aqsa dan Masjid Al-Manar. Nama ini secara simbolik menjadi tanda adanya hubungan antara Masjid Kudus dengan Baitul Maqdis dari Palestina, di samping karena masjid ini dibangun dengan menggunakan batu dari Baitul Maqdis sebagai batu pertama.

Menara dan gapura masjid Kudus didesain mirip dengan bangunan candi.Hal ini merupakan prinsip adopsi dan adaptasi antara unsur-unsur arsitektur Jawa-Hindu dan Budha-dengan nilai-nilai arsitektur Timur Tengah (Islam). Secara geografis, Arab yang beriklim panas tidak sesuai dengan Indonesia yang keadaan iklimnya mengalami pergantian musim (kemarau dan penghujan), dan selain memang kesediaan material yang berbeda memberikan ciri arsitektur Isnus, khususnya di Jawa, sangat khas. Terkait masjid, arsitektur Islam-Arab, atapnya biasanya berbentuk kubah, ornamen-ornamen berbentuk geometris, menara berbentuk tabung serta denah berbentuk kotak. Adapun arsitektur Islam-Jawa atapnya berbentuk meru, ornamen berbentuk organis/floral, menara berbentuk candhi Hindu, serta denah dipengaruhi oleh organisasi ruang 'dalem' rumah Jawa. Bentuk arsitektur masjid, khususnya di Jawa pada era Wali Songo, mengalami akulturasi dan bahkan transformasi di mana kedua kebudayaan

dipertemukan dan direinterpretasikan terus- menerus ke arah bentuk kebudayaan baru dengan tidak kehilangan identitas dari masing-masing kebudayaan asal. Tiga unsur yang menjadi penyangganya adalah ide, aktivitas, dan artefak.

Dalam sejarah perkembangan arsitektur Islam, kebudayaan lokal memainkan peranan penting. Misalnya, pada 691 M di Palestina didirikan masjid setelah wilayah itu ditaklukkan pasukan Islam dari penguasa Romawi yang telah tujuh abad menduduki wilayah Palestina. Arsitek dan para pekerjanya diambil dari orang-orang Romawi, sehingga gaya bangunan masjid merupakan persenyawaan antara Byzantium dan Arab. Masjid ini dikenal dengan Dome of Therock atau Kubah Batu. Perlu disadari bahwa dalam konteks budaya, Islam tidak perlu membuang kebudayaan lama dan menggantinya dengan yang baru, sejauh tidak bertentangan dengan prinsip Islam. Sebelumnya peristiwa ini, kebudayaan Islam-Arab tidak mengenal kubah. Struktur bangunan dengan atap kubah adalah produk asli kebudayaan Romawi. Dengan mengoptimalkan material dasar berupa bebatuan, bangsa Romawi merupakan pioner dalam teknologi rancang bangun. Mereka menciptakan struktur bentang lebar untuk menghindari banyaknya kolom-kolom penyangga. Hal serupa yang dilakukan para wali di tlatah Jawa. Bangunan masjid tradisional di Jawa merupakan pengembangan dari 
arsitektur tradisional Jawa itu sendiri, yaitu bangunan tajug (bangunan berdenah bujur sangkar), beratap piramid, dan memiliki 4 tiang yang dikenal dengan istilah sokoguru. Tiga tingkatan atap tajug dengan mustaka di puncaknya menjadi karakter eksternal masjid-masjid di Jawa. Jumlah atap tumpang pada bangunan masjid melambangkan tingkatan dalam ajaran tasawwuf, yaitu syari'at, thariqat, ma'rifat, dan haqqiqat.

\section{Masjid-masjid tradisional di} Jawa adalah perpaduan antara budaya agama Islam dengan budaya Jawa-Hindu. Secara simbolik, ia menjadi ruang arsitektural di mana unsur-unsur lokal didialogkan dengan unsur-unsur luar, dalam hal ini adalah Arab-Islam. Secara spiritualarsitektural, sebagai tempat ibadah, oleh para wali di Jawa, masjid dijadikan ruang penghormatan terhadap tradisi leluhur. Sunan Kudus, bahkan pernah mengikat seekor sapi yang sangat istimewa di halaman masjid Kudus, sebagai strategi dakwah, sehingga masyakarat di sekitar masjid - yang ketika itu masih memeluk agama Hindu - berdatangan ke masjid, menyaksikan sapi yang diperlakukan istimewa tersebut. Bukan hanya itu, beliau bahkan melarang masyarakat muslim Kudus untuk memakan daging sapi yang dikeramatkan dalam kepercayaan Hindu-meskipun dalam Islam diperbolehkan. Kearifan Sunan Kudus ini, dalam sejarah yang panjang hingga sekarang masyarakat Kudus, secara budaya, berpantang makan daging sapi. Maka, di Kudus tidak ditemukan ada menu makanan Soto dengan daging sapi.

\section{LANGKAH DAN POLITIK ISLAM NUSANTARA}

Di bagian ini, difokuskan pada strategi kebudayaan Walisongo dalam membentuk Isnus, yang salah satunya juga menggunkaan media seni. Dan, seperti telah dijelaskan di bagian awal buku ini, masuk dan berkembangnya Islam di Indonesia tidak bisa dilepaskan dari kesejarahan yang panjang bagi Ibu Pertiwi. Sebelum Islam hadir, masyarakat Nusantara telah mengenal dan menjalankan sistem budaya dan religi yang begitu kompleks dan kosmopolit. Beragam bentuk kebudayaan dan praktek keagamaan membaur menjadi warna khas bagi bangsa khatulistiwa ini. Berangkat dari itu, maka sulit bahkan tidak mungkin kekayaan budaya lokal dicabut dari akarnya begitu saja, bahkan oleh sistem budaya, dan strategi apa pun.

Dengan wujud dan formasi keagamaannya, Islam pun tidak mungkin memaksakan diri untuk menolak budaya yang ada di Nusantara. Meletakkan posisi vis a vis antara Islam dan budaya Nusantara, berarti memaksakan kehendak untuk disingkirkan oleh arus besar kelompok yang meyakini akan terciptanya akulturasi budaya IslamIndonesia. Pada masa awal perkembangannya inilah tampak betapa peran penting kesejarahan 
Islam di Indonesia dimainkan secara apik oleh para Wali dan Ulama, sehingga sifat Islam yang akomodatif tersebut dapat diterima dengan mudah oleh masyarakat setempat. Nilai-nilai universal seperti keadilan, persamaan dan kemanusiaan, mendapatkan porsi yang luas dalam Islam. Berdasarkan inilah, Islam pada masa awal perkembangannya mampu bersimbiosis dengan budaya lokal, yang sudah barang tentu pula mengedepankan prinsip-prinsip yang sama. Titik temu ini selanjutnya dikemas dalam format dakwah (khususnya oleh para Wali) yang tidak melulu mendudukkan masyarakat lokal sebagai tertuduh dan salah, akan tetapi mereka disadarkan dengan berangkat dari kekayaan pengetahuan yang telah dimilikinya. Salah satu budaya yang paling penting diajukan adalah tradisi wayang, yang dikemas sedemikian rupa oleh para Wali, sehingga mampu dijadikan ruang 'ideologisasi' masyarakat setempat untuk masuk Islam.

Dengan demikian, Islam masuk ke Nusantara tidak serta merta menghancurkan seluruh kebudayaan masyarakat. Karena para Ulama waktu itu mendakwahkan Islam dengan menggunakan strategi kebudayaan. Tidak heran jika dalam beberapa kasus, Islam justru mengakomodasi budaya yang sedang berjalan di masyarakat Nusantara. Seperti contoh, kesenian wayang yang sudah berlangsung lama dibiarkan berjalan untuk selanjutnya diberi makna baru oleh para Ulama. Contoh demikian menunjukkan bahwa, Islam sebagai sebuah tradisi yang berinteraksi dengan tradisi lain seringkali menciptakan tradisi baru. Sebuah tradisi hasil hibridasi antara Islam di satu sisi dan tradisi lokal pada sisi yang lain. Pada masyarakat Jawa, hasil hibridasi ini kemudian dikenal dengan Islam-Jawa (dalam lingkup yang lebih luas dikenal dengan Islam Nusantara) yang merupakan bentukan dari akulturasi dengan kebudayaan lokal. Kenyataan ini semakin memperkokoh pandangan bahwa Islam tidaklah hanya berupa sekumpulan doktrin. Melainkan juga, Islam dihayati dan diamalkan oleh para pemeluknya menjadi sebuah realitas kebudayaan. Dengan begitu, akulturasi budaya antara Islam dan kebudayaan lokal adalah bagian dari sekian banyak ekspresi Islam sebagai pandangan hidup dan sumber inspirasi bagi tindakan para pemeluknya.

Selain wayang, banyak jenis kesenian lain yang mendapat sentuhan Islami dari para ulama, dengan tidak menghilangkan tradisi yang telah ada sebelumnya. Kreatifitas para ulama dalam mencipta kesenian ini sangat terkenal semasa Walisongo, seperti diciptakannya berbagai permainan edukatif (Jamuran, Cublak Suweng, Ilirilir), tembang-tembang keagamaan (Mocopat), seni ukir bermotif, seni musik (gamelan), seni pahat, dan berbagai corak seni lainnya. Peninggalan Walisongo ini sampai saat 
ini masih bisa ditemukan di Nusantara, bahkan dikembangkan oleh ulama-ulama setelahnya.

Berdasarkan inilah, maka Islam yang muncul dan berkembang di Indonesia tidaklah seperti yang ada di Arab atau Timur Tengah, yang umumnya sebagai agama negara yang ajarannya dapat dijadikan hukum negara. Sebaliknya, Islam di Indonesia mampu melakukan proses sublimasi, sehingga nilai-nilainya meresap dalam setiap perilaku anak bangsanya dan dijadikan modal untuk membangun negeri ini. Dan model Islam seperti inilah yang dinamakan sebagai Islam Nusantara, Islam dapat diterima dengan lapang dada oleh masyarakat lokal di Nusantara karena ajarannya telah mengupayakan pembebasan atas keterkungkungan masyarakat feodal yang telah ada sebelumnya, yang tidak membuang tradisi yang sudah melekat di masyarakat, melainkan menyempurnakannya dengan sentuhan-sentuhan Islami, yang tidak lagi memandang perbedaan kasta, suku, dan warna kulit, dan tentu saja yang disebarkan tidak dengan kekerasan, melainkan dengan kemuliaan akhlak dan ketinggian ilmu para ulama' nya.

Ulama yang terkenal dalam menyebarkan Islam di Nusantara (khususnya pulau Jawa) adalah Walisongo. Walisongo secara sederhana artinya sembilan orang wali, sedangkan secara filosofis maksudnya sembilan orang yang telah mampu mencapai tingkat wali, suatu derajat tingkat tinggi yang mampu mengawal babahan hawa sanga (mengawal sembilan lubang dalam diri manusia), sehingga memiliki peringkat wali. Di dalam Ensiklopedi Islam disebutkan bahwa Walisongo adalah sembilan ulama pelopor dan pejuang pengembangan Islam di Pulau Jawa pada abad ke-15 (masa Kesultanan Demak). Para ulama ini dianggap telah dekat dengan Allah SWT, terus menerus beribadah kepada-Nya, serta memiliki kekeramatan dan kemampuan-kemampuan lain di luar kebiasaan manusia, sebagaimana diungkapkan Tarwilah dalam "Peranan Walisongo dalam Pengembangan Dakwah Islam".

Menurut KH. Bisyri Musthafa, sebagaimana diuraikan oleh Saifuddin Zuhri, jumlah para wali itu tidak hanya sembilan, tetapi lebih dari itu. Agaknya sembilan orang wali itu adalah mereka yang memegang jabatan dalam pemerintahan sebagai pendamping raja atau sesepuh kerajaan di samping peranan mereka sebagai mubalig dan guru. Oleh karena mereka memegang jabatan pemerintahan, mereka diberi gelar Sunan, kependekan dari susuhunan atau sinuhun, artinya orang yang dijunjung tinggi. Bahkan kadangkadang disertai dengan sebutan Kanjeng, kependekan dari kang jumeneng, pangeran atau sebutan lain yang biasa dipakai oleh para raja atau penguasa pemerintahan di daerah Jawa.

Walisongo yang terkenal dalam mengembangkan Islam di Pulau Jawa adalah Sunan Gresik, Sunan Ampel, 
Sunan Bonang, Sunan Drajat, Sunan Kalijaga, Sunan Giri, Sunan Kudus, Sunan Muria, dan Sunan Gunung Jati. Peran Walisongo dalam penyebaran Islam di Nusantara, terutama di Jawa sangatlah besar. Dalam banyak catatan disebut, bahwa Walisongo adalah perintis awal gerakan dakwah Islam di Nusantara. Karena jika dilihat pada fase sebelumnya, Islamisasi di Nusantara lebih dilaksanakan oleh orangperorangan tanpa manajemen organisasi. Tetapi pada masa Walisongo, aspek manajemen keorganisasian telah difungsikan. Yakni, mereka dengan sengaja menempatkan diri dalam satu kesatuan organisasi dakwah yang diatur secara rasional, sistematis, harmonis, tertentu dan kontinyu serta menggunakan strategi, metode dan fasilitas dakwah yang betul-betul efektif. Apabila berita tentang Walisongo dikumpulkan dan dipelajari, antara lain dari Serat Walisongo dan dari Primbon milik Prof. KH. R. Moh. Adnan, maka dapat disimpulkan, bahwa secara keseluruhan -kecuali Syeik Siti Jenar- Walisongo adalah satu kesatuan organisasi, yang dapat diidentikkan sebagai panitia ad hoc atau kanayakan (kabinet) urusan meng-Islamkan masyarakat Jawa. Beberapa artikel dalam islamnusantara.com, menjelaskan soal ini. Terbukti, masing-masing Wali memegang peranan dan bertanggungjawab sebagai ketua bagian, seksi atau nayaka (menteri) dan sebagainya dalam organisasi dakwah Walisongo itu. Mereka sering berkumpul bersama, pemusyawarah, merundingkan berbagai hal yang berkenaan dengan tugas dan perjuangan mereka. Bukti lain yang menunjukkan Walisongo sebagai kesatuan organisasi, adalah peristiwa pembangunan masjid Demak, dimana dalam peristiwa itu tercermin sebuah kerjasama dan gotong royong untuk kepentingan dan tujuan yang sama; yaitu untuk kepentingan syiar agama Islam.

Pemahaman Walisongo dan generasi sesudahnya di Indonesia terhadap agama dan budaya membuat mereka dapat menghargai kebudayaan dan situs budaya lokal yang telah ada dan terus berkembang. Mereka menjaga sikap toleran dan inklusiftransformatif tersebut walaupun mereka pada akhirnya menjadi masyarakat mayoritas. Oleh karena itu, hingga sekarang kita masih dapat menyaksikan megahnya candi Borobudur, candi Prambanan, candi GedongSongo, Menara Kudus, danlainlain. Kreasi seni yang dipromosikan Walisongo selalu mengapresiasi budaya setempat. Hal itu semua dilakukan oleh Walisongo untuk menghormati budaya setempat dengan menginternalisasikan ajaran Islam. Bahkan, penghargaan terhadap tradisi juga masih ada yang berkembang hingga sekarang. Sebagai contoh, larangan Sunan Kudus bagi masyarakat Muslim Kudus untuk tidak memakan daging sapi, masih dijaga hingga sekarang meskipun mereka mengetahuinya sebagai halal. Hal itu dilakukan 
sebagai bentuk dari toleransi budaya yang menyatu dalam dirimereka.

Sejarah juga membuktikan bahwa Walisongo telah berhasil membangun masyarakat Muslim dalam lingkungan budaya Hindu, Budha, animisme, dan dinamisme yang sudah mengakar kuat di masyarakat. Kunci keberhasilannya sangat dimungkinkan karena strategi akulturasi budaya yang dilakukannya tersebut. Walisongo tidak melakukan penetrasi atau penggeseran secara frontal budaya lokal dengan budaya Islam karena hal itu mereka pandang sesuatu yang sulit dan tidak efektif. Sebaliknya, mereka melakukan akulturasi budaya antara nilai-nilai Islam dengan instrumen kebudayaan setempat.

Dalam proses akulturasi, kebudayaan lokal tetap dimanfaatkan sebagai instrumen kebudayaan Islam. Adapun peran Islam lebih bersifat mengisi substansi nilai-nilai yang ada dengan merevisi beberapa atau mengganti sama sekali nilai-nilai yang tidak cocok dengan filosofi Islam. Hal itu semua dilakukan secara bertahap. Proses sejarah yang panjang telah membuat proses akulturasi tersebut berjalan dengan baik, yakni beberapa bentuk kebudayaan masyarakat masih tetap ada, namun kebudayaan tersebut sesungguhnya merupakan kebudayaan yang baru karena nilainilai yang dibawanya merupakan nilai yang baru.

Hal ini menjelaskan bahwa pola akulturasi yang berlangsung terus- menerus sehingga Islam pada akhirnya akan menjadi mainstream kebudayaan masyarakat. Pada awalnya, Islam mengambil beberapa instrumen kebudayaan yang ada. Selanjutnya, instrumen budaya yang diambil oleh Islam semakin lama semakin banyak. Seiring dengan pengembangan pengambilan instrumen budaya yang terus berkembang, Islam selalu memasukkan nilai Islam di dalamnya. Pengembangan nilai-nilai Islam dalam setiap budaya yang diambil akan semakin kuat sehingga budaya tersebut menjadi bagian dari budaya Islam. Proses demikian yang berlangsung terus tentu akan melebarkan budaya Islam sekaligus nilai-nilai Islam dalam kehidupan masyarakat. Akumulasi dari akulturasi budaya inilah yang pada akhirnya melahirkan budaya Islam sebagai kebudayaan baru yang ada dan menyatu dalam kehidupan masyarakat.

Namun demikian, perlu dipahami bahwa akulturasi bukanlah integrasi budaya atau sinkretisme-meskipun dalam batas tertentu hal itu mungkin pula terjadi. Jika dilihat, proses akulturasi yang dilakukan oleh Walisongo bukanlah bentuk integrasi ataupun sinkretisme budaya. Walisongo tidak mengintegrasikan antara kebudayaan Islam dengan kebudayaan lokal, tetapi mereka mengambil instrumen kebudayaan lokal untuk diisi dengan nilai-nilai keislaman. Mereka tidak pula melakukan sinkretisme karena 
nilai-nilai teologi keislaman tidak dipadukan atau dicampuradukkan dengan nila-nilai teologi lokal. Hal itu sekali lagi dilihat sebagai bentuk akulturasi budaya yang dialektis dan dinamis. Maksudnya, Walisongo membangun dan mengembangkan budaya Islam dengan basis kebudayaan lokal.

Model akulturasi Islam seperti ini tidak hanya cocok ketika umat Islam Indonesia masih dalam tahap pengenalan dan dalam kondisi minoritas lemah, tapi juga relevan ketika umat Islam telah menjadi umat mayoritas dan kuat. Karena, respon antara Muslim esensialis dan muslim realis tentunya berbeda dalam menanggapi persoalan ini. Bagi kaum esensialis yang terpenting adalah diamalkannya ajaran Islam oleh masyarakat, sedangkan budaya adalah instrumen saja. Sebaliknya, kaum realis memandang bahwa kebudayaan adalah hakikat dari agama itu sendiri. Kaum realis dengan lebih menekankan karakteristik generik - seolah-olah menganggap hubungan antara budaya dengan agama ibarat hubungan generik antara gula dengan manis ataupun bahan pembuatnya. Menurutnya, ketiga entitas (gula, rasa manis, dan bahan dasar gula) tersebut secara generik bersifat satu-kesatuan. Sebaliknya kaum esensialis sudah berkenan memberikan pembedaan gula dari manis dan unsur pembentuknya karena hakikat manis tidak hanya terdapat dalam gula; tidak semua gula mempunyai kadar manis yang sama; dan gula tidak hanya terbuat dari pohon tebu, aren, dan kelapa.

Dalam kasus pengadopsian
wayang ke dalam bagian dari
kebudayaan Islam, kaum realis akan menolak wayang untuk dijadikan sebagai unsur kebudayaan Islam karena bercorak Hindu. Baginya, wayang dipandang identik dengan Hindu dan tidak mungkin bisa dilepaskan sisi ke-Hindu-annya. Oleh karena itu, mereka menganggap sulit mengambil wayang sebagai instrumen kebudayaan Islam. Sebaliknya, kaum esensialis memandang bahwa wayang adalah instrumen budaya yang isinya dapat berupa nilai apa saja. Dimensi kehinduan dalam pakem dan plot cerita pewayangan bukanlah karakter absolut. Sebaliknya, dimensi nilai-nilai dalam pakem dan plot cerita sebenarnya bersifat netral sehingga dapat diisi dengan nilai apa saja yang memungkinkan.Oleh karena itu, mereka melihat sisi kemungkinan untuk mengadopsi wayang sebagai instrumen kebudayaan Islam setelah mereformulasi nilai-nilainya dengan nilai-nilai Islami.

Ibaratnya, kaum realis hanya menonjolkan pengetahuan generik bahwa gula terbuat dari tebu, aren ataupun kelapa. Sebaliknya, kaum esensialis-yang secara spesifik memberikan konsen terhadap unsur kimiawi gula dan zat manis - bersedia menjelaskan bahwa ada kemungkinan gula yang dapat diekstrak dari tumbuhan yang lain, seperti jagung, palawija, ataupun rerumputan. Berdasarkan analogi 
tersebut, kaum esensialis melihat bahwa tujuan Islam adalah untuk mencetak manusia yang baik, yakni mempunyai hubungan yang baik dengan sesama, dengan Tuhan dan alam. Adapun caranya, bisa memanfaatkan bentuk-bentuk budaya apapun yang memungkinkannya untuk dikonstruksi dengan formulasi esensi ajaran Islam. Sebaliknya, kaum realis lebih merujuk pada teks suci al-Qur'an dan perilaku Rasullullah yang terkodifikasi dalam Hadis, yang keduanya dipahami secara literalistik. Mereka menganggap bahwa keduanya merupakan pilar utama dari kebudayaan Islam dalam maknanya yang literalistik.

Kedua pandangan tersebut sebenarnya mempunyai tujuan yang sama, yakni memelihara ajaran Islam dan menjaga eksistensi umat Islam. Namun demikian, perbedaan titik tolak pandangan keduanya tentang kebudayaan dan esensi ajaran Islam telah mengakibatkan terjadinya perbedaan antara keduanya. Dalam realitas empirik, umat Islam yang memiliki pendirian ekstrim seperti tersebut tidak ada, tetapi pandangan tersebut muncul dalam konformasi tertentu.

Dalam kasus Indonesia, sulit ditemukan anatomi secara jelas organisasi sosial keagamaan Islam dengan pendirian yang ekstrim esensialis ataupun ekstrem realis. Yang ada adalah percampuran antara keduanya dalam konformasi tertentu. Sebagai contoh, dalam organisasi
Muhammadiyah ditemukan dua corak pemahaman tersebut dalam konformasinya yang selalu berkembang. Di kalangan NU, pemahaman tersebut juga muncul dalam konformasi yang selalu berkembang. Memang memungkinkan ada pendapat yang mengatakan, bahwa NU lebih mudah menerima budaya lokal daripada Muhammadiyah. Hanya saja, hal itu tidak sepenuhnya benar karena dalam banyak kasus, masyarakat masingmasing organisasi tersebut juga melihat budaya lokal sebagai bagian dari cara ekspresi keagamaan. Untuk memahami problem penerimaan akulturasi oleh masyarakat muslim, maka perlu dilakukan pembedaan antara terma tersebut dengan termaterma lain yang sering dianggap sama, yakni sinkretisme dan inkhiraf. Karena, sinkretisme dan khurafat mesti akan ditolak oleh mayoritas umat Islam, tetapi hanya sedikit yang menolak akulturasi budaya. Dalam kasus Indonesia, penerimaan tersebut dapat dilihat dari dua varian organisasi sosial Islam di Indonesia, NU dan Muhammadiyah. Oleh karena dua organisasi sosial dengan jumlah massa terbesar di Indonesia dapat menerima akulturasi budaya, maka dapat dikatakan bahwa masyarakat Islam di Indonesia dapat menerima sistem akulturasi budaya.

Perbedaannya hanyalah kadar penerimaan mereka; dan hal itu merupakan fenomena yang bersifat dialektis dan dinamis. Meskipun penerimaan model akulturasi budaya 
sudah menunjukkan pola pandang keberagamaan yang inklusif, namun masih dalam kategori eksklusif karena masih ada monopoli kebenaran yang dilakukan atas nama agama. Sebenarnya, jika dilihat dari perspektif filsafat budaya, maka tidak ada yang salah dengan sinkretisme maupun yang dalam istilah Arab dikenal dengan tahrif. Secara filosofis, semua pemahaman manusia tentang Tuhan dan ajarannya bersifat nisbi sesuai dengan batas kemampuan nalar manusia dan latar belakang budaya yang melingkupinya. Apa yang dinamakan Tuhan dan ajaran Tuhan adalah persepsi manusia tentang Tuhan dan ajaran-Nya. Cara pandang demikianlah yang memungkinkan umat Islam lebih bijaksana dalam memahami varian keberagamaan di antara mereka-bahkan dalam memahami tradisi umat beragama yang lain.

Dalam kerangka pikir demikian, antara yang menerima sistem akulturasi budaya maupun yang menolak sistem akulturasi budaya sebenarnya sama-sama bermaksud untuk menjaga eksistensi Islam dan kemajuan peradaban umat Islam. Oleh karena itu, perbedaan yang terjadi antara keduanya perlu dianggap sebagai proses dinamika yang akan selalu menuju pemantapan bagi pembangunan dan pengembangan kebudayaan Islam. Jika dilihat lebih cermat lagi, maka dapat ditemukan bahwa perbedaan tersebut sebenarnya berakar dari perbedaan dalam memahami esensi ajaran Islam dan kebudayaan yang dibangun masyarakat Muslim.

\section{DAFTAR PUSTAKA}

Abdur Rozaki, Menabur Kharisma Menuai Kuasa: Kiparah Kiai dan Blater sebagai Rezim Kembar di Madura, Yogyakarta: Pustaka Marwa, 2003.

Abdurrahman al-Bagdadi, Seni dalam Pandangan Islam (Vocal, Musik, Tari), Jakarta: Gema Insani, 2004.

Abdurrahman Mas'ud, “The Religion of

Pesantren" dalam Interna- tional

Conference on Religious Harmony:

Problem, Practice, and Education in

Yogyakarta-Semarang,

September-3 Ok- tober 2004.

Sunyoto, Atlas Walisongo, Bandung:

Mizan, 2012.

Agus Sunyoto, Atlas Walisongo, Jakarta:

Pustaka Ilman, Trans Pusta- ka dan LTN PBNU, 2012.

Agus Sunyoto, Wali Songo, Rekonstruksi

Sejarah yang Disingkirkan,Jakarta:

Trans Pustaka, 2011.

Ahmad Baso, NU Studies: Pergolakan Pemikiran Antara Fundamen- talisme Islam dan Fiundamentalisme NeoLiberal, Jakarta: Er- langga, 2006.

Budiman, Arief, Teori Negara; Negara, Kekuasaan dan Ideologi, Ja- karta: Gramedia, 1996.

Deliar Noer, Gerakan Modern Islam di Indonesia, Jakarta: LP3ES, 1996.

Denys Lombard, Nusa Jawa Silang Budaya Kajian Sejarah Terpadu, Bagian II: Jaringan Asia, Gramedia; Jakarta, 1996. 
Loupias, Henry H., “Budaya Agraris Hindia Belanda", da- lam Pikiran Rakyat, 4 September 2008.

Herbet Feth dan Lance Castle, Pemikiran Politik Indonesia,1945-1965, Jakarta: LP3ES.

John D. Legge, Sukarno; Sebuah Biografi Politik, Jakarta: Sinar Hara- pan, 1985.
Julia Day Howell, "Modernity and Islamic Spirituality In Indonesia's New Sufi Networks", dalam Martin van Bruinessen, dan Ju- lia Day Howell (ed.), Sufism and "The Modern" in Islam, New Yorl: IB Tauris \& Co Ltd, 2007.

Jurnal ITTIHAD, Jurnal Kopertis Wilayah XI Kalimantan, Volume 4, No.6, 2006

Jurnal KOMUNIKA, Jurusan Dakwah STAIN Purwokerto, Vol.2 No.2 JulDes 2008 
|| Turãst:Jurnal Penelitian \& Pengabdian Vol. 6, No. 2, Juli-Desember 2018 